\title{
SOME RESTRICTIONS ABROAD AFFECTING CORPORATIONS
}

\author{
Phanor J. Eder*
}

Modern commercial law stems from the medieval law merchant, a cosmopolitan law of, by and for a cosmopolitan community, designed to do away with or mitigate the distinction between subject and stranger. The modern corporation, however, stems from the monopolies granted by the Crown to favored subjects, in the mercantilist era, for the purpose of trading with, or even preying upon, foreign countries.

Under the law merchant, partnerships could be freely formed without royal charter and without regard to nationality. What more natural then that, under the Liberal school, it should be deemed an inherent right of merchants to freely form joint stock companies or business corporations without having to ask for any special authorization? Are they not merely an extended partnership with limited liability?

Not all countries, however, were willing to follow the example of the leading trading nations in permitting commercial freedom of association. Enough of the monopoly idea survived, and has continued to survive, to impose the requirement of a special authorization at the discretion of the Executive as a prerequisite to the organization of a corporation, and to further impose discriminations against foreign investors, managers and employees. The restrictions are sometimes statutory. More frequently they result from the practical working out of the executive discretion allowed by the statutes. The latter aspect must be especially borne in mind.

The underlying idea persists that there is something sacrosanct, some aura of divine grace, in a grant of juristic personality with limited liability. Foreigners from many countries who come to the United States are amazed at the facility, rapidity and economy with which corporations are organized for every conceivable business by any butcher, baker or candystick maker. At home, they still look upon corporations as designed for big business only and hence, if foreign, to be potentially dangerous and therefore to be hedged with every conceivable safeguard for national sovereignty and domestic economy; or, if domestic, to be used as a special grant of favor to political partisans or personal friends. ${ }^{1}$

- Special student University of Liege, Belgium, I897-I898; A.B., 1900, College of the City of New York; LL.B., 1903, Harvard University. Member of the New York Bar; honorary member Colombian Academy of Jurisprudence. Director, Comparative Law Division, Section of International and Comparative Law, American Bar Association. Chairman, Committee on Foreign Law, New York County Lawyers Association. Author of several baoks and contributor to legal periodicals.

${ }^{1}$ This article does not deal with the limited liability partnership (société de responsabilité limitée, etc.) much used on the Continent and in recent years introduced in Latin-American legislation. It is generally unsuitable for foreign capital, being more like a partnership, with unlimited authority in the partners, prohibitions on public subscriptions to shares or bonds and on the issuance of negotiable certificates of stock in any form, the interest being assignable only with the consent of the company. Houpin \& Bosvieux, Traité Général des Sociétés (7th ed. I935) 75I et seq. 
The stronger a country is the readier it will be to treat alien and national alike. In fact, it is prosperous and strong because it does so. The history of the great trading centers and bourses furnishes many an instance. Antwerp, Amsterdam, Lyons, Hamburg, etc., successively were prosperous because they were free to all, national and alien, on equal terms. In the nineteenth century, London (with Paris second) was the financial center of the world, supplying capital to build America, which needed it and had no fear of it. Our own restrictions on aliens are anachronisms.

The principle of freedom of association, the right to organize business corporations under general laws, without special government license-so familiar to us that we take it for granted-became the rule of the principal commercial countries of Europe only late in the nineteenth century-England ( 1844$),{ }^{2}$ Spain ( 1869 and Commercial Code 1885), Germany (1870), France (1873), Italy (Commercial Code 1882), etc. The British Dominions patterned their laws on England. .

The principle was not followed in other countries or was severely limited (Austria, Finland, Greece, Portugal, Russia, Serbia, Syria). Nor, despite the strong influence of French, Spanish and Italian law, was the principle universally followed in Latin America. The present situation is that executive authorization is required in Argentina, Bolivia, Chile, Guatemala, Haiti, Honduras, Uruguay. In one or two others the theory is not denied, but the corporation bureaus (Superintendency of Share Companies) tend to stretch their authority to the limit of or beyond the law. Under the guise of determining whether or not a proposed corporation meets the requirements of the statutes, they exercise an arbitrary discretion which goes unchallenged, since no lawyer or businessman will care to antagonize the authorities or delay his start by appeal to the courts.

Where executive discretion is the rule, the opportunity for discrimination against foreign interests is obvious, and will be availed of if there is a tendency in government circles towards xenophobia in general or against a particular nationality that happens to be in disfavor at the moment. Equally obvious, in reverse, is the opportunity for favoritism. The choice of the right lawyer or intermediary may be vital.

In the other Ibero-American countries, special authorization is not required for ordinary business companies but only for special types of business. In recent years, the exceptions have tended to become more and more numerous, as they did in Europe prior to the war. Banking, insurance, hydroelectric and other utilities and public works, oil and mining are amongst the most frequent instances, authority for which rests in the discretion of the President or Ministers.

In both Europe and Latin America, the Registrar of Commerce or the commercial or district judge may have to pass on the conformity of the papers to the general law. While sometimes these officers are inclined to be extremely technical, I have never personally met with any instance of discrimination against foreign interests.

= In this article, footnotes and citations have been deliberately kept to the minimum. If the writer does not furnish chapter and verse, for every statement he makes, he invites the reader to accept him on faith. 
Where special executive authorization is required for domestic companies, it is usually required in order to domicile foreign corporations. Conversely, where the principle of freedom of association is recognized, foreign corporations may be freely registered; a few exceptions may be noted-Brazil, Dominican Republic, Mexico (usually, however, given automatically if the statutory requirements are met). Argentina, which requires executive license for domestic companies, does not require it of foreign companies, but only on proof of reciprocity-proof difficult to establish for American companies. A dangerous feature in those countries is that the licenses to foreign companies are usually revocable-true, only for violation of law, or action harmful to national economy, but it is not too difficult for an official to find a violation if he is bent upon finding one. The Venezuelan Code, following the Italian, provides that companies constituted abroad which have their principal seat of business in the country are considered Venezuelan.

\section{Restrictions on Aliens}

In general, foreign corporations or domestic corporations infested, as local thought might have it, with a substantial foreign interest, are subject to the same restrictions that are imposed on individual aliens. Most modern constitutions or civil codes enunciate the general principle that aliens enjoy the same civil rights as nationals. ${ }^{3}$ However, in many countries, these rights are so whittled down by special laws or administrative practices that the general provision has become somewhat insignificant. A frequent limitation is on the right to own immovables generally or rural property in particular or lands within a specified distance from the frontier or the coast. The prohibition is sometimes absolute, sometimes subject to executive discretion. It frequently extends to mines, oil, waters and hydroelectric plants; other frequent prohibitions are as to ownership of ships and aircraft and communication facilities, and engaging in banking and insurance, less frequently as to government contracts, newspapers and education. Coastwise shipping and air cabotage are usually restricted to nationals or even to native-born citizens. Some countries (e.g., Portugal, Italy) prohibit aliens from establishing new factories or purchasing existing ones without special executive authorization. In Mexico, the disabilities can sometimes be overcome by agreeing to be considered a national, for the particular purpose, and waiving right to diplomatic protection under penalty of forfeiture. In the case of corporations, this provision has to be inserted in the articles of association and in stock certificates. A somewhat similar provision (the so-called Calvo clause) usually insisted upon in all contracts with the government in Latin-American countries has often prevented business being consummated, notwithstanding our State Department does not recognize the validity of the clause.

In the inter-war period, rampant autarchy and extreme nationalism infected large areas of the world. These manifestations, which could not fail to impose restrictions

\footnotetext{
${ }^{3}$ Among progressive countries, Sweden was a notable exception, having imposed rather severe disabilities on aliens by the Laws of May 30, 1916 and of June II, 1937. The 1941 Constitution of Panama, as compared with the former liberality toward aliens, was a surprising retrogression.
} 
on the activities of aliens and corporations, were not confined to countries bent on military aggression. Strangely enough, the Nazi-socialist corporation law of $1937,{ }^{4}$ while introducing some substantial reforms, on the whole did not depart from traditional law, nor did it restrict nor exclude foreign interests in corporations. The subordination of enterprise, German equally with foreign, to the State was accomplished by other means, not by the corporation statutes.

State monopolies also greatly restrict the opportunities available to foreign capital. The recent trend towards government ownership ${ }^{5}$ in such leading countries as Great Britain and France will doubtless lead to imitation unless a countercurrent be set in motion by the efforts of the United States.

Where restrictions of the character above mentioned are imposed on individual aliens, they almost invariably apply to foreign corporations and also very generally prevent shares in domestic corporations, or at least a majority or substantial interest, being held by foreign interests. In the latter case, bearer shares are prohibited. A few countries, however, are satisfied with a domestic company regardless of the nationality of the shareholders, sometimes coupled with the proviso that the managers and all or a majority of the directors be citizens. In a couple of countries, some of the prohibitions are not against aliens, but only against non-residents.

\section{Personnel}

There is rarely any prohibition against aliens or even non-residents being incorporators and shareholders of ordinary business companies. Indeed to impose a bar on the holding of shares by aliens would be incompatible with the practice of bearer shares which is expressly permitted for full-paid stock under nearly all corporation statutes other than in the Anglo-American countries. A recent trend, it is true, is manifest against bearer shares, largely due to income tax motives. The French law of November 13, r933, permits double voting rights to be accorded to nominative (i.e., registered) shares. In some of the South American countries, the Superintendent of Share Companies refuses to permit bearer shares, notwithstanding the express permission in the statute. Provisions in by-laws limiting the right to hold or vote shares to nationals are held valid in France and would doubtless be upheld generally. As already pointed out, where special kinds of business are limited to nationals or national companies free from foreign control or participation, a prohibition against bearer shares is generally coupled to the limitation.

Not only must there be a minimum number of incorporators (varying from 2 to Io), but the minimum number of shareholders must be continued under penalty of dissolution. The penalty is occasionally expressed in the statute, sometimes im-

'See generally Ernst Mezger, Le Nouveau Régime des SociEttes Anonmmes en Altemagne (Paris, 1939).

"It is better to avoid the term "nationalization," as in Latin America this gencrally means only the transfer from foreign ownership to native, not government, ownership-a process sometimes called "naturalization." The tendency has undoubtedly been accentuated by the confiscation and sale to natives of enemy property during the war. It is to be feared that it will not be a transitory trend, but will be extended to friendly aliens, unless an active educational campaign is pursued. 
plied as a matter of general law. Under English and Italian law, the owner of a "one-man" company is personally liable. Elsewhere it is customary when a company owns a roo percent beneficial interest in a subsidiary to have dummy shareholders. This device, common as it is with us, is not without danger abroad. Under the influence of French jurisprudence, the application of the doctrine of "fraud against the law" is becoming more frequent, especially in Latin America. Authorities unfriendly to foreign capital or instigated by a disgruntled competitor or discharged employee, might readily find a useful weapon in this doctrine.

We are also familiar with the requirement that one or more of the directors must be citizens and/or residents of the state of incorporation. There is no such restriction in the majority of foreign statutes, but even where there are similar requirements only occasionally do they cause any inconvenience to American interests. That is where the statute (as in Brazil) calls for a larger number of directors than can conveniently be found if the choice is limited to citizens of the country. In line with what we said about maintaining a minimum number of shareholders, it must be borne in mind that in several countries, directors must be shareholders (e.g., France, Great Britain, Argentina, Salvador, some of the Swiss cantons). In Cuba, the secretary of the corporation must be a Cuban lawyer.

Much more serious difficulties for American-owned companies operating abroad are to be found in the labor laws. In Western European countries, technicians and skilled labor will be available. Not so in Latin America and the East. The labor laws usually require a certain high percentage in number and/or total payroll of laborers and "employees" (white collar workers and technical men) to be citizens. As to engineers and other technicians, skilled artisans and confidential office workers, the handicap may verge on disaster for the foreign owner. Human nature is as it is; one is more prone to understand, fully confide in and achieve smoothest teamwork with one's own countrymen, high though be the respect and regard for others. Restriction of choice violates the essence of sound management. One expedient is to pad the payroll with natives, but this is equally contrary to sound business principles. These requirements of the labor laws as to higher employees are in conflict with the spirit, if not the letter, of several of the commercial treaties with the United States which grant reciprocal rights to traders to select their own agents. ${ }^{6}$ Further, they impede the progress and dampen the prosperity of undeveloped countries, whose crying need is technical training and experience. It should not be too hard a task to convince even the particular professions which have been most active in fostering such ultranationalistic legislation that it is not conducive to their own best long-range interests.

\footnotetext{
- Thus, Art. VII of the Treaty of $\mathrm{I} 85 \mathrm{I}$ with Costa Rica provides that "all merchants . . . and others, citizens of the United States, shall have full liberty, in all the territories of the Republic of Costa Rica, to manage their own affairs themselves, or to commit them to the management of whomsoever they please. ..." I TREATtes (MaILOY) 34I, 343. Language of similar import is found generally in treaties of "friendship, commerce and navigation," e.g., treaties with: Colombia ( 1846 ) Art. 7, I Tresties (Mrllox) 302; Paraguay (I859) Art. IX, = id. 1364, I366; Argentina (1853) Art. VIII, I id. 20, 22; Honduras (1864) Art. VI, $\mathrm{r}$ id. $952,954$.
} 


\section{Voting Limitations}

Another, this time unintended, discrimination detrimental in practical operation to foreign interests is caused by limitations on the voting power of majority stockholders. They may be embarrassing, indeed harmful to the safe conduct of a business, and are a deterrent to that association of American with local capital which is now being so generally advocated. That a majority should not exercise autocratic control, well and good. That it be deprived of full power of management is intolerable from any sane business standpoint. Stalemates are disastrous. In forty years practice, I have never found a single instance where divided control proved satisfactory.

The Italian Code of Commerce gives each stockholder one vote for each share up to 5 ; a holder of 5 to roo shares has only I vote for each 5 shares, and a holder of more than I00, only I vote for each 25 shares. This seems to have been the origin of many of the unsatisfactory provisions in Latin-American statutes. Bolivia, Costa Rica and Uruguay follow the Italian system with minor variations. In Colombia, no shareholder can vote more than 25 percent of the total stock issued and outstanding. In Argentina (as in Portugal), no one can vote more than ro percent of the total outstanding or 20 percent of the stock represented at the meeting.

These prohibitions are evaded in practice by having the stock split up of record among many supposed holders. Such a subterfuge runs the risk of being declared illegal, at any opportune moment, as a fraud on the law. These limitations also tend to alarm prospective foreign investors.

The Mexican system should commend itself to other Latin-American countries. The holders of 20 percent of the stock are entitled to elect one director and one member of the supervisory and audit committe and have certain rights of recourse to the courts. Under it, American and Mexican interests in the last few years have been quite willing to enter into joint ventures.

There are many hindrances to foreign investment and foreign trade more serious than those above pointed out. Exchange controls, undue control of capital issues, tariffs, labor conditions, taxation and, above all, security against confiscation in any guise or form must be first looked at. Corporate restrictions may, however, weight the scale. The restrictions herein dealt with, and some others of analogous character, are symptomatic of unhealthy condition. In the social sciences, by curing the symptoms we can sometimes move towards curing or mitigating the cause. Every effort should be made by trade associations and officials everywhere to remove needless hindrances and to secure passage of general laws with a minimum of administrative discretion. Many of the restrictions, it is obvious, are short-sighted measures working to the disadvantage of the countries that adopt them. They are, as the Latins say, contraproducentes. They produce results the opposite of what their sponsors intended. 
The needs of the world are reciprocal. To maintain world prosperity, essential to our own prosperity, effective world demand must be sustained. If we are to retain foreign markets for our products, the United States must be ready not only to increase imports but to invest and reinvest abroad any balance of payments. In its own interest, it must live up to the responsibilities corresponding to its role as the leading factor in world economy.

The dire need of other countries for capital is self-evident, yet we find that in many of them, the expressed desire for foreign capital is a mere day-dream, not a working aspiration. Any country must avoid giving the impression that it wants capital on terms reminiscent of the old vaudeville skit: the bank is open when you want to deposit, it is closed when you want to withdraw. As to the frequent utterance that foreign capital is welcome but only if it is willing to conform to the laws, it may be observed that in fact foreign companies are more scrupulous in obeying the laws than native capitalists, not from any superior morality but from a keen realization that honesty is the only policy when the authorities are ever gunning for foreigners. It is not sufficient that laws or treaties provide against discriminationdiscrimination must cease, in fact, if there is to be a full flow of capital and technical skill into the undeveloped regions of the world.

The Bretton Woods agreements and whatever may come out of the Social and Economic Council of UN will prove a poor substitute for the mobility of private capital and of skill that characterized and made for the prosperity of the world in the nineteenth and early twentieth centuries. We must seek to recapture this mobility. The advantages of the division of labor, fundamental tenet of the Liberal school, are no less evident in the international realm than in the domestic field. Corporations are its most useful legal mechanism. Let them work untrammeled. 